\title{
Atmospheric Dry Deposition in the Proximity of Oil-Fired Power Plants at Mexican Pacific Coast
}

\author{
R. M. Cerón ${ }^{1 *}$, J. G. Cerón ${ }^{1}$, C. Aguilar ${ }^{1}$, C. Montalvo ${ }^{1}$, C. Carballo $^{1}$, B. Cárdenas ${ }^{2}$, A. Ortinez $^{2}$, \\ M. Cocom ${ }^{1}$, J. Carrillo ${ }^{1}$ \\ ${ }^{1}$ Research Center on Environmental Sciences, Autonomous University of Carmen, Carmen City, Mexico; ${ }^{2}$ National Center for \\ Training and Environmental Research, National Institute of Ecology, Mexico City, Mexico. \\ Email: rceron@pampano.unacar.mx
}

Received May 29 ${ }^{\text {th }}, 2012$; revised June $28^{\text {th }}, 2012$; accepted July $27^{\text {th }}, 2012$

\begin{abstract}
Dry deposition samples were collected in a weekly basis during 2010 in a site located at the Mexican Pacific Coast: Manzanillo, Colima. Samples were collected with an automatic wet/dry deposition sampler using nylon filters as surrogate surfaces. Samples were extracted with deionized water and analyzed for $\mathrm{pH}$, conductivity, $\mathrm{Na}^{+}, \mathrm{K}^{+}, \mathrm{Ca}^{2+}, \mathrm{Mg}^{2+}$, $\mathrm{NH}_{4}^{+}, \mathrm{NO}_{3}^{-}, \mathrm{SO}_{4}^{2-}$ and $\mathrm{Cl}^{-}$. Nitrate and sulfate were the most abundant ions, contributing with $53 \%$ to the total ionic mass; and their levels exceeded the hemispheric background concentrations proposed for marine remote sites. The influence of the power plants burning combustoleo located upwind the sampling site was completely evident. From meteorological analysis, it could be observed that the sampling site was all time under the influence of power plants as a result of the effect of breezes. However, in spite of the high levels of $\mathrm{NO}_{3}^{-}$and $\mathrm{SO}_{4}^{2-}$ found in the samples collected, $\mathrm{pH}$ value average was almost neutral, with $28 \%$ of samples slightly acid. Potassium was the most abundant cation and from the quantification of the neutralization effect of the main alkaline components, the prevalence role of $\mathrm{K}^{+}$was completely evident, suggesting the influence of the mining complex Peña Colorada located upwind the sampling site, where amyl xanthate potassium is used as collector in tailing dams. Dry deposition fluxes were estimated for all ions measured. Nitrogen dry deposition at Manzanillo is already in the upper extreme of the threshold value reported for sensible ecosystems. On the other hand, sulfur deposition exceeded slightly the critical load value reported for some ecosystems in Europe. Even at this moment, nitrogen and sulfur deposition is not a problem, it is necessary to take steps to avoid that total deposition of these elements exceeds critical loads, considering that results reported in this study not include the wet deposition fluxes.
\end{abstract}

Keywords: Dry Deposition; Dry Fluxes; Oil-Fired Power Plants; Combustoleo; Mexico

\section{Introduction}

Atmospheric deposition is the process by which airborne pollutants are deposited to the terrestrial surface. These pollutants include, but are not limited to, sulfur dioxide, nitrogen oxides, ammonia and mercury. There are two ways that acids fall out of the atmosphere: wet and dry deposition. Together with wet deposition, dry deposition is responsible for delivering atmospheric loads of compounds such as $\mathrm{SO}_{4}^{2-}, \mathrm{NO}_{3}^{-}$and $\mathrm{NH}_{4}^{+}$to the ecosystems. Wet deposition involves atmospheric hydrometeors which scavenge aerosol particles predominantly by rain and snow, but also by clouds and fog. In the other hand, dry deposition of particles and gases occurs by complex processes such as settling, impactation and adsorption.

The significance of the "acid rain" issue has been well

"Corresponding author. established since several years ago, however, it is necessary to note that in the total load of acids to the surface (soils, vegetation and water bodies), precipitation is one component of this problem but not the unique, in such a way that dry deposition should be also considered [1].

Atmospheric deposition has been largely studied in different sites and locations around the world during the last years, and it has been found that episodes of acid rain are directly related to industrial emissions, being the main contributors the power plants burning fuel and coal [2]. Many areas with acid deposition have been identified and studied [3], and the important role that plays the industrial facilities near the sampling sites has been pointed out. In spite of procedures to collect wet deposition are available anywhere since several years, quantifying dry atmospheric deposition is a difficult task due to the 
complex chemical processes involved [4] and standardized procedures to collect it are not available.

It is well known that dry deposition is related to local emissions, whereas wet deposition reflects long-range transport phenomena and it is more connected with regional sources. Therefore, wet and dry deposition measurements are essential for understanding regional variations, local influence by anthropogenic or geochemical sources and long-range transport processes. In the last years, energy consumption in Mexico as a result of the industrial and urban development has increased significantly. Currently, approximately $68 \%$ of generated energy comes from burning "combustoleo" (a blend of residua and gas oil cutter stock that meets the viscosity requirements of ASTM D 396), resulting in fly ash emission and large amounts of acid precursors $\left(\mathrm{SO}_{2}\right.$ and $\mathrm{NO}_{\mathrm{x}}$ ).

In 2010, the Mexican Environmental Agency (SEMARNAT) supported a research project focused on the study of atmospheric deposition in sites located in the surroundings of power plants burning "combustoleo". This work reports the assessment of the chemical composition of dry deposition in one of these sites: Manzanillo, Colima; located at the Pacific Coast.

\section{Materials and Methods}

\subsection{Sampling Site Description}

Manzanillo, Colima is situated in the Pacific Coast of Mexico. Population in the city is approximately of 161,420 inhabitants and has a total surface of $1578.4 \mathrm{~km}^{2}$; being the biggest municipality of the Colima State. Climate is sub-humid warm (Aw) with summer rains, temperature ranges from $22^{\circ} \mathrm{C}$ to $28^{\circ} \mathrm{C}$. Since Mexico is influenced by the monsoon, the study area shows two periods well defined: the dry season (from November to Mayo), and the rainy season (from June to October). Figure 1 and Table 1 show the geographical position and main characteristics of the sampling site. High excess sulfate has been reported in rainwater samples in Manzanillo [5], and it has been concluded that this sul-

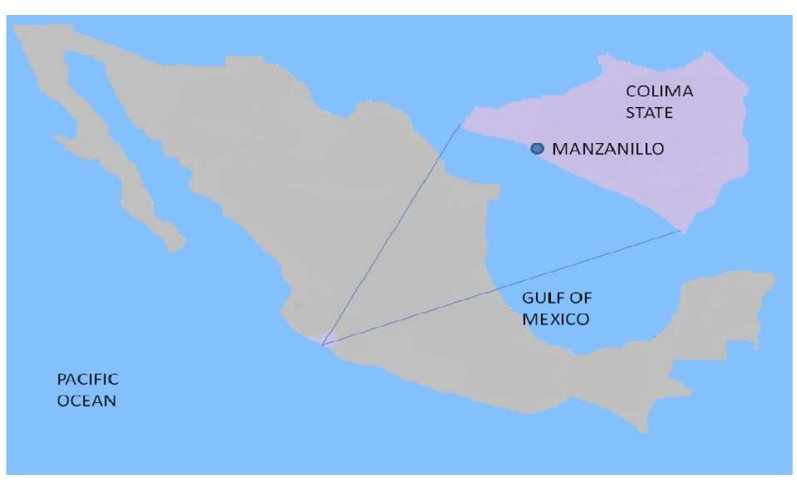

Figure 1. Location of the sampling station.

fate excess had a predominant anthropogenic background origin. This sulfate excess can be explained from two sources: the long-range transport from Guadalajara City, because Manzanillo is located downwind from this important urban and industrialized area (trade winds blow from this direction during the summer); and two fossilfueled power plants that operate continuously, located in this site.

Characteristics and capacity of these power plants are shown in Table 2. Since this site is a coastal city, it is subject to the effect of sea and land breezes. Visual observations indicate that power plant plumes clearly enhance the formation of low level clouds which are transported to the sampling site.

Observations in this site, also indicate that Manzanillo is subjected to the air masses transported locally by the action of breezes. In addition, there is one more source contributing to excess sulfate, calcium, potassium and chloride levels: the mining mill complex Peña Colorada.

\subsection{Sampling and Analysis}

Dry deposition samples were collected on a weekly basis for a period of one year (2010). In this study, dry deposition was assessed using a surrogate surface according to the methodology proposed by Alonso et al [6]. Sampling was performed by using an automatic wet-dry deposition collector. This sampler is equipped with two polyethylene buckets and a lid controlled by a humid sensor

Table 1. Main features of the sampling station.

\begin{tabular}{ccccc}
\hline Site & Type area & Annual average rainfall (mm) & Altitude (m·asl) & Lat. \\
\hline Manzanillo, Colima & Urban and industrial & 983 & 4 & $19^{\circ} 02^{\prime} 35^{\prime \prime} \mathrm{N}$ \\
\hline
\end{tabular}

Table 2. Main characteristic of the power plants located in the vicinity of the sampling site considered in this study.

\begin{tabular}{cccc}
\hline Power plant & Date of the beginning of operation & Units & Effective capacity installed (MW) \\
\hline M. Alvarez Moreno-Manzanillo I & September 1, 1982 & 4 & 1200 \\
Manzanillo II & July 24, 1989 & 2 & 700 \\
\hline
\end{tabular}


which moves depending on the beginning and the end of the rain event. Three nylon filters (Nylasorb, Pall Corporation, Gelman Lab, Michigan, USA; 47 mm diameter, 1 um pore-size) were used as surrogate surfaces. Filters were exposed in horizontal position on a filter support within the dry deposition bucket. Dry deposition fluxes were estimated from surface area and time exposure.

Samples were taken to the laboratory immediately after collection and stored at $-18^{\circ} \mathrm{C}$ until analysis. Nylon filters were extracted with $80 \mathrm{ml}$ of deionized water for $15 \mathrm{~min}$ in an ultrasonic bath. The first filter extract was used to measure $\mathrm{pH}$, conductivity and ammonium (colorimetrically using a spectrophotometer UV HACH DR 2800). The second extract was subjected to an acid digestion in Teflon closed flasks (Cole-Parmer) of $100 \mathrm{ml}$, using autoclave equipment as energy source. Extracts digested were analyzed for $\mathrm{Na}^{+}, \mathrm{K}^{+}, \mathrm{Ca}^{2+}$ and $\mathrm{Mg}^{2+}$ by atomic absorption spectrophotometer (Thermo scientific ICE 3300). Finally, the third filter extract was used to determine $\mathrm{Cl}^{-}, \mathrm{SO}_{4}^{2-}$ and $\mathrm{NO}_{3}^{-}$by ion chromatography (Agilent 1100).

The detection limits were estimated as three times the standard deviation of six blank samples. Repeatability was assessed by analyzing samples from at least 3 replicate measurements, maintaining a coefficient of variation $<5 \%$ for all ions measured. The analytical precision was maintained by running known standards after 15 samples. Analytical precision for cations and anions was within $10 \%$. The quality of analytical data was checked by a cation-anion balance. Like an additional quality assurance measure, a comparison between measured conductivity with the calculated conductivity was considered. If the differences are less than $10 \%$, it can be assumed that all the major ions have been analyzed. Ionic balance calculations (Figure 2) and conductivity differences revealed that all main ions were analyzed for Manzanillo.

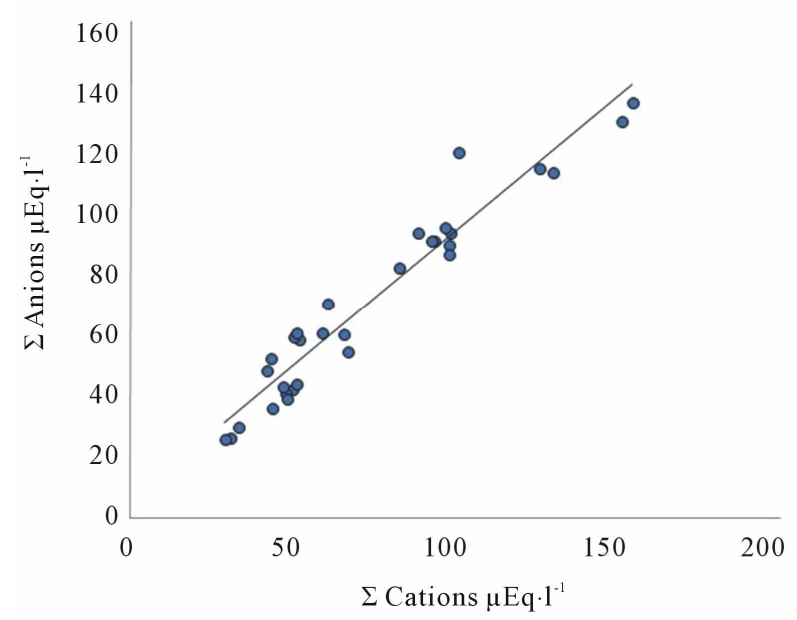

Figure 2. Quality control (ionic balance) of chemical analysis for dry deposition samples collected in Manzanillo.

\subsection{Meteorological Data}

To obtain surface meteorological data, a portable meteorological station (Davies Inc.) was operating in the sampling site during the whole study period. Wind roses were obtained by using WindRose from NOAA Air resources Laboratory.

From Figure 3, it can be observed that prevailing winds came from NW for Manzanillo during the study period. In addition, to trace the origin of the air masses during the study period, air-mass backward trajectories were obtained daily $48 \mathrm{~h}$ before using NOAA HYSPLIT Model. It can be observed that during the study period, air masses came from NW (Figure 4), just from the power plants located near the sampling site.

\section{Results and Discussion}

Minimum, maximum and average values of concentration of major ionic components and $\mathrm{pH}$ are given in Table 3.

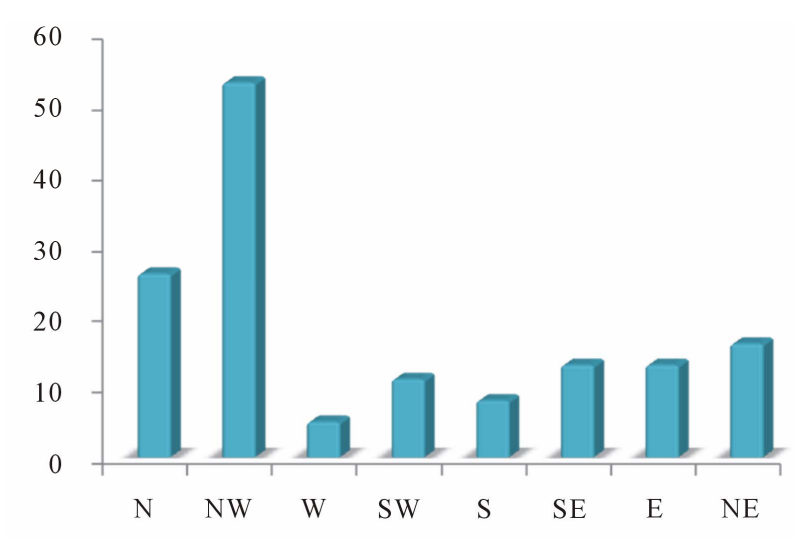

Figure 3. Wind direction frequency distribution for Manzanillo during the study period.

Table 3. Minimum, maximum and average concentration of major ions $\left(\mu \mathrm{Eq} \cdot \mathrm{l}^{-1}\right)$ and $\mathrm{pH}$ in dry deposition samples collected at Manzanillo.

\begin{tabular}{cccc}
\hline Parameter & Minimum & Maximum & Average \\
\hline $\mathbf{p H}$ & 5.06 & 6.94 & 5.76 \\
$\mathbf{N a}^{+}$ & 0.04 & 2.65 & 0.76 \\
$\mathbf{K}^{+}$ & 17.90 & 341.69 & 46.36 \\
$\mathbf{C a}^{2+}$ & 0.02 & 69.83 & 10.49 \\
$\mathbf{M g}^{2+}$ & 1.48 & 6.75 & 3.04 \\
$\mathbf{N H}_{4}^{+}$ & 0.03 & 74.83 & 21.98 \\
$\mathbf{N O}_{3}^{-}$ & 7.26 & 84.03 & 26.52 \\
$\mathbf{S O}_{4}^{2-}$ & 15.61 & 124.66 & 46.66 \\
$\mathbf{C l}^{-}$ & 0.04 & 2.06 & 0.61 \\
\hline
\end{tabular}



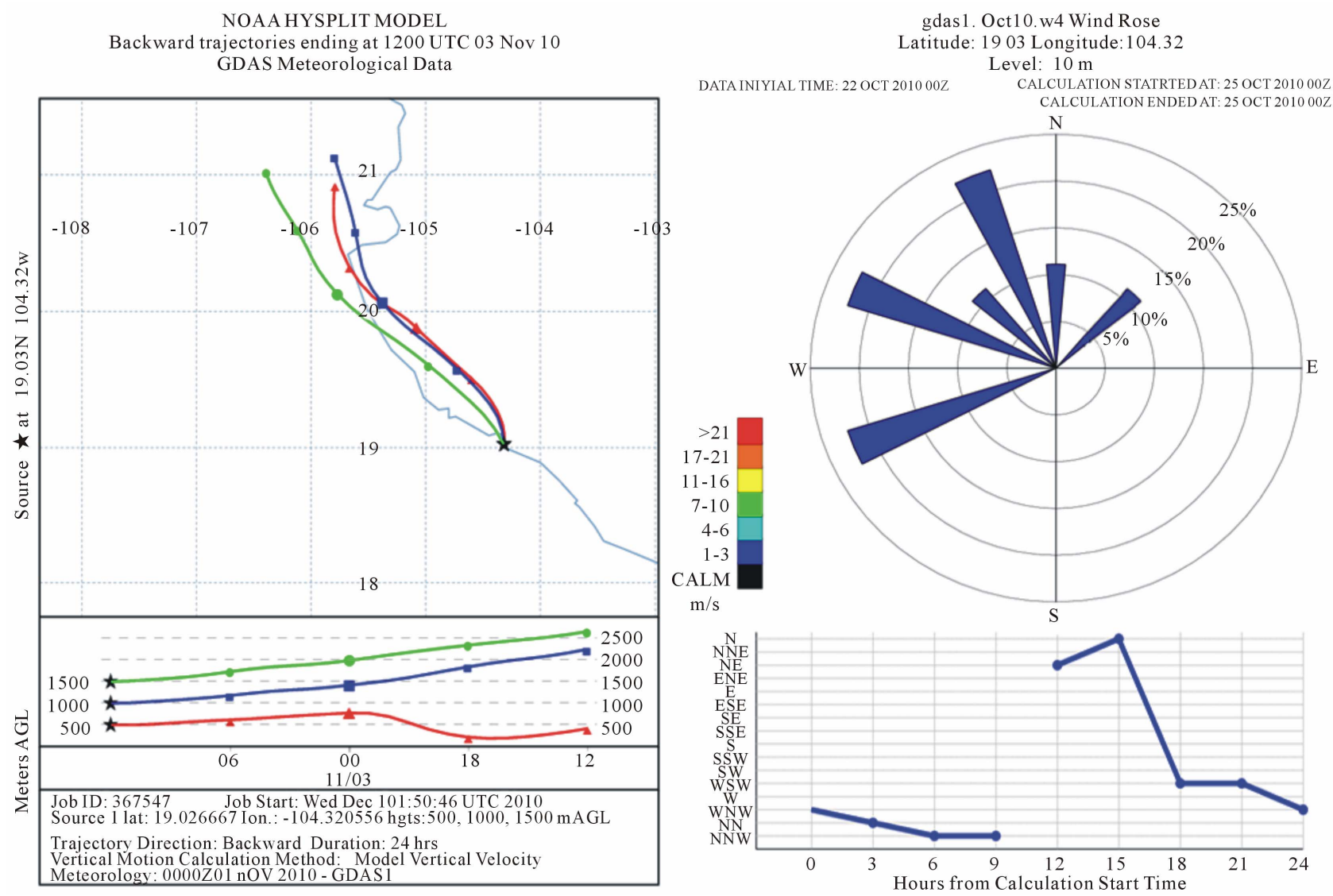

Figure 4. Typical backward air mass trajectory and wind rose for Manzanillo during the study period.

\section{1. pH and Ocurrence of Acidic Events}

The analytical data shows that $\mathrm{pH}$ of collected dry deposition samples ranged between 5.06 and 6.94, with an average value of 5.76, indicating a neutral nature of dry deposition samples (Figure 5). The frequency distribution for $\mathrm{pH}$ (in percentage) shows the number of slightly acidic events recorded at Manzanillo was $28 \%$. In spite of nitrate and sulfate levels were high as a result of the proximity of the sampling site to the power plants, $\mathrm{pH}$ values obtained were not acid, it suggests that $\mathrm{HNO}_{3}$ and $\mathrm{H}_{2} \mathrm{SO}_{4}$ were subjected to neutralization processes that lead to $\mathrm{pH}$ values almost neutral.

\subsection{Chemical Composition and Source Identification}

\subsubsection{Chemical Composition}

The contribution percentage of cationic components $\left(\mathrm{Na}^{+}, \mathrm{K}^{+}, \mathrm{Ca}^{2+}, \mathrm{Mg}^{2+}\right.$ and $\left.\mathrm{NH}_{4}^{+}\right)$towards the total ion mass balance was $47 \%$, and acidifying components $\left(\mathrm{SO}_{4}^{2-}, \mathrm{Cl}^{-}\right.$, and $\left.\mathrm{NO}_{3}^{-}\right)$accounted $53 \%$ of total ionic mass. Figure 6 shows the individual contribution of different ions towards the total ionic mass. $\mathrm{K}^{+}$and $\mathrm{NH}_{4}{ }^{+}$ were the dominant cations contributing with $31 \%$ and $11 \%$ of the total ionic mass. Among anions, $\mathrm{SO}_{4}^{2-}$ was the predominant anion followed by $\mathrm{NO}_{3}^{-}$, contributing with $30 \%$ and $23 \%$ of the total ionic mass, respectively.

High sulfate levels were comparable to those found in sites with anthropogenic influence. The average sulfate excess concentration $\left(\mathrm{SO}_{4}^{2-}\right)_{\mathrm{xs}}$ was $22.5 \mu \mathrm{Eq} \cdot 1^{-1}$, almost three times higher than $\left(\mathrm{SO}_{4}^{2-}\right)_{\mathrm{xs}}$ background hemispheric concentration proposed by Galloway et al. [7] for

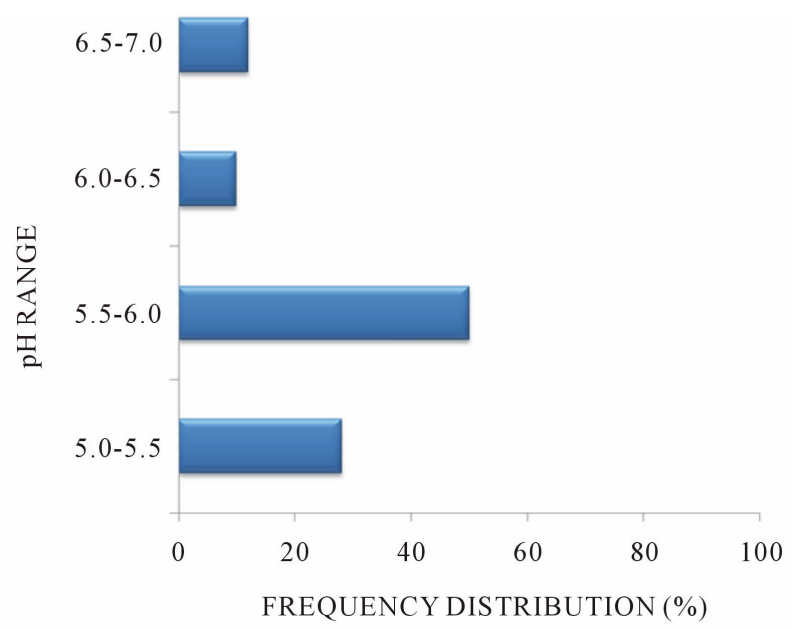

Figure 5. Frequency distribution for $\mathrm{pH}$ at the study site (\%). 


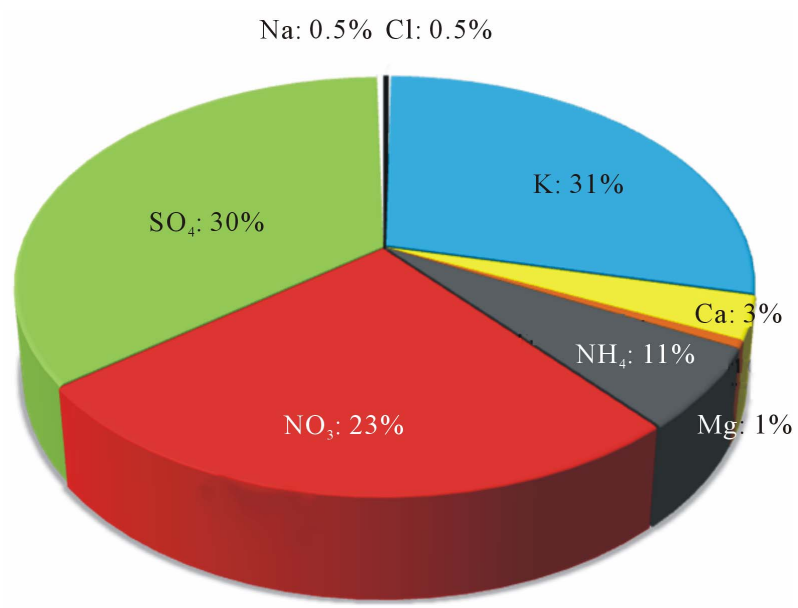

Figure 6. Contribution of different ionic species toward the total ionic mass.

marine remote sites $\left(10 \mu \mathrm{Eq} \cdot \mathrm{l}^{-1}\right)$. On the other hand, high nitrate levels also were found $\left(16.53 \mu \mathrm{Eq} \cdot l^{-1}\right)$. These values exceeded the $\mathrm{NO}_{3}^{-}$background hemispheric concentration proposed by Casimiro et al. [8] for coastal and marine remote sites $\left(2.8 \mu \mathrm{Eq} \cdot 1^{-1}\right)$, suggesting an evident influence of local anthropogenic sources.

\subsubsection{Marine Aerosol Contribution}

The chemical composition of atmospheric deposition in coastal sites is controlled by local atmospheric dust/particulate, natural and anthropogenic emissions, and marine contribution. It is difficult to evaluate the relative contribution of different sources to the total sulfate concentration in deposition collected in oceanic and coastal sites. Even in remote sites, sulfate excess levels have been found [7]. A common method involves the use of a tracer derived from marine aerosol where sea salt is the reference source. Therefore, it is necessary to define the excess as the fraction with an origin different from the sea salt, this excess is frequently assessed in terms of an enrichment factor (EF) [9].

Chemical composition of sea water is expressed as the ratio between the concentration of the element and the concentration of chloride ion, and it has reported elsewhere $[10,11]$. In coastal and marine sites, it is assumed that relative ratios of elements as $\mathrm{Na}^{+}, \mathrm{K}^{+}, \mathrm{Ca}^{2+}, \mathrm{Mg}^{2+}$, $\mathrm{Cl}^{-}$and $\mathrm{Br}^{-}$in atmospheric deposition present similarity to those reported for sea water. However, depending on the influence of other sources like natural and anthropogenic sources, these ratios can be different to those expected for sea water [12].

To assess the marine aerosol contribution, the enrichment factors (EF) are commonly used, an EF approaching to the unity suggests that the trace element is originnated in sea salt (not enriched elements). On the other hand, and EF greater the unity suggests that a significant fraction had origin in a source different than sea salt (enriched elements). The enrichment factors (EF) of different ions with respect $\mathrm{Cl}^{-}$were calculated by Equation (1), where $\mathrm{X}$ is the ion of interest and $\mathrm{X} / \mathrm{Cl}^{-}$is the ratio between the concentration of the element and the concentration of chloride ion in deposition samples.

$$
\mathrm{EF}=\frac{\left(\frac{\mathrm{X}}{\mathrm{Cl}^{-}}\right)_{\text {depositionsample }}}{\left(\frac{\mathrm{X}}{\mathrm{Cl}^{-}}\right)_{\text {seawater }}}
$$

From equivalent ratios of major ions in dry deposition samples and the corresponding values in sea water, it could be observed that all ratios were higher than those expected for sea water. In addition, the enrichment factors were greater than the unity, indicating that non-marine sources contributed to the measured ions. Assuming that all $\mathrm{Cl}^{-}$in deposition samples originated from sea salt, the contribution of non-marine sources was calculated as follows: $90 \%$ for $\mathrm{SO}_{4}^{2-}, 82 \%$ for $\mathrm{K}^{+}, 24 \%$ for $\mathrm{Ca}^{2+}$, and $7 \%$ for $\mathrm{Mg}^{2+}$.

Significant anthropogenic air pollution sources were present in Manzanillo and it is clear that these modified in a strong way the chemical composition of dry deposition collected in this site.

High levels of sulfate excess were present in samples collected during the study period, suggesting the influence of the emissions from power plants located upwind the sampling site; this percentage is in agreement with the sulfate excess reported by Padilla et al. [5] in rainwater samples in this site.

The high percentage of non-sea salt fractions of $\mathrm{K}^{+}$ and $\mathrm{Ca}^{2+}$ indicate the non-marine contribution and the influence of the local terrestrial sources, probably soil particles and the mining mill complex Peña Colorada located upwind the sampling site. It has been reported that dry deposition is generally related to local emissions [13], therefore we can conclude that all enriched elements $\left(\mathrm{SO}_{4}^{2-}, \mathrm{K}^{+}, \mathrm{Ca}^{2+}\right.$ and $\left.\mathrm{Mg}^{2+}\right)$ had their origin in local sources: soil particles, and emissions from oil-fired power plants and mining complex located upwind and in the vicinity of the sampling site.

\subsubsection{Correlation between Ion Pairs and Source Identification}

Correlation coefficients between analyzed ions are also used to hypothesize the possible origin of trace elements. Significant correlations can indicate common sources or transport processes, a great contribution to the acidity or an important role in neutralization processes. Correlation coefficients between ion pairs in dry deposition samples collected in Manzanillo were calculated and are given in Table 4. 
Table 4. Inter-elemental correlation matrix for dry deposition samples collected.

\begin{tabular}{|c|c|c|c|c|c|c|c|c|}
\hline & $\mathrm{Na}^{+}$ & $\mathbf{K}^{+}$ & $\mathrm{Ca}^{2+}$ & $\mathbf{M g}^{2+}$ & $\mathbf{N H}_{4}^{+}$ & $\mathrm{NO}_{3}^{-}$ & $\mathrm{SO}_{4}^{2-}$ & $\mathrm{Cl}^{-}$ \\
\hline $\mathbf{N a}^{+}$ & 1 & & & & & & & \\
\hline $\mathbf{K}^{+}$ & 0.06 & 1 & & & & & & \\
\hline $\mathrm{Ca}^{2+}$ & 0.61 & 0.11 & 1 & & & & & \\
\hline $\mathbf{M g}^{2+}$ & 0.14 & 0.39 & 0.47 & 1 & & & & \\
\hline $\mathbf{N H}_{4}^{+}$ & 0.03 & 0.05 & 0.12 & 0.01 & 1 & & & \\
\hline $\mathrm{NO}_{3}^{-}$ & 0.14 & 0.75 & 0.22 & 0.56 & 0.49 & 1 & & \\
\hline $\mathbf{S O}_{4}^{2-}$ & 0.26 & 0.71 & 0.29 & 0.50 & 0.50 & 0.93 & 1 & \\
\hline $\mathrm{Cl}^{-}$ & 0.78 & 0.04 & 0.03 & 0.24 & 0.09 & 0.01 & 0.14 & 1 \\
\hline
\end{tabular}

As can be observed from Table 4 and Figure 7, $\mathrm{SO}_{4}^{2-}$ and $\mathrm{NO}_{3}^{-}$showed a significant correlation $(\mathrm{r}=0.93)$ in samples indicating their origin in similar sources as a result of the emissions from their precursors $\mathrm{SO}_{2}$ and $\mathrm{NO}_{\mathrm{x}}$, in this case, from fuel oil-fired power plants located upwind the sampling site. $\mathrm{Na}^{+}-\mathrm{Cl}^{-}(\mathrm{r}=0.78)$ and $\mathrm{Na}^{+}-$ $\mathrm{Ca}^{2+}(\mathrm{r}=0.61)$ were good correlated, suggesting a marine origin since these elements are derived from marine aerosol.

On the other hand, significant correlations between $\mathrm{SO}_{4}^{2-} \mathrm{K}^{+}(\mathrm{r}=0.71)$ and $\mathrm{NO}_{3}^{-}-\mathrm{K}^{+}(\mathrm{r}=0.75)$ probably result from the reaction of acids with alkaline compounds emitted from the mining complex Peña Colorada (amyl xanthate potassium is used as collector in tailing dams) and alkaline particles present in the crustal dust.

\subsection{Neutralization Factor}

The interaction between cations and anions can be described by the neutralization factor (NF). Neutralization of acids by cations is validated by the calculation of neualization factors (Equation (2)):

$$
\mathrm{NF}_{\mathrm{X}=}\left[\frac{\mathrm{X}}{\left(\mathrm{NO}_{3}^{-}\right)+\left(\mathrm{SO}_{4}^{2-}\right)}\right]
$$

where $\mathrm{X}$ is the component of interest $\mathrm{y}\left(\mathrm{NO}_{3}^{-}\right)$and $\left(\mathrm{SO}_{4}^{2-}\right)$ are the concentrations for nitrate and sulfate ions, respectively.

To verify which cation $\left(\mathrm{Ca}^{2+}, \mathrm{K}^{+}\right.$and $\left.\mathrm{NH}_{4}{ }^{+}\right)$more frequently neutralized the acidic components in dry deposition, neutralization factors (NF) were estimated and a triangular diagram was drawn (Figure 8).

The triangle relating the neutralization factor of $\mathrm{Ca}^{2+}$, $\mathrm{K}^{+}$and $\mathrm{NH}_{4}^{+}$revealed that $\mathrm{K}^{+}$was the predominant neutralizer. It is well known that the high concentrations of $\mathrm{K}^{+}$are related to the surface soil and mining activities. Neutralization factors demonstrated that potassium played an important role in the neutralization process, suggesting probably the presence of $\mathrm{KNO}_{3}$ and $\mathrm{K}_{2} \mathrm{SO}_{4}$ in the atmosphere, originating from alkaline particles derived from the earth crust and the mining complex Peña Colorada, and from $\mathrm{SO}_{2}$ and $\mathrm{NO}_{\mathrm{x}}$ emitted in combustion processes in power plants.

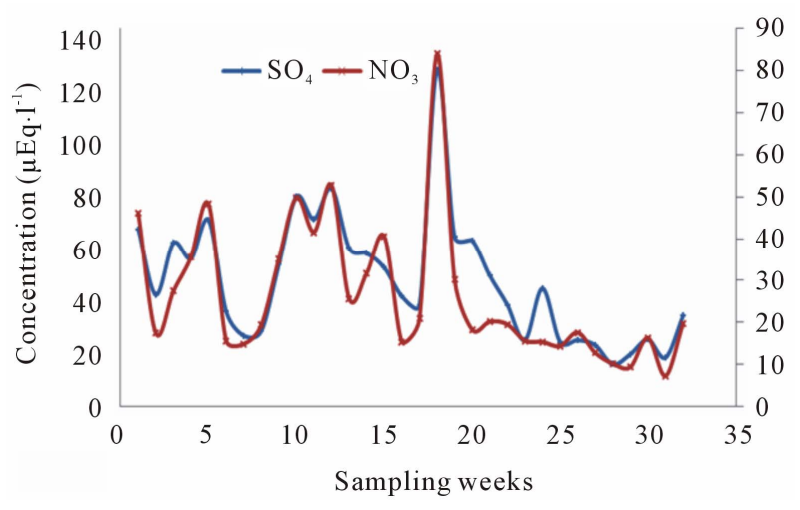

Figure 7. Variation diagram between $\mathrm{SO}_{4}^{2-}$ vs $\mathrm{NO}_{3}^{-}$.

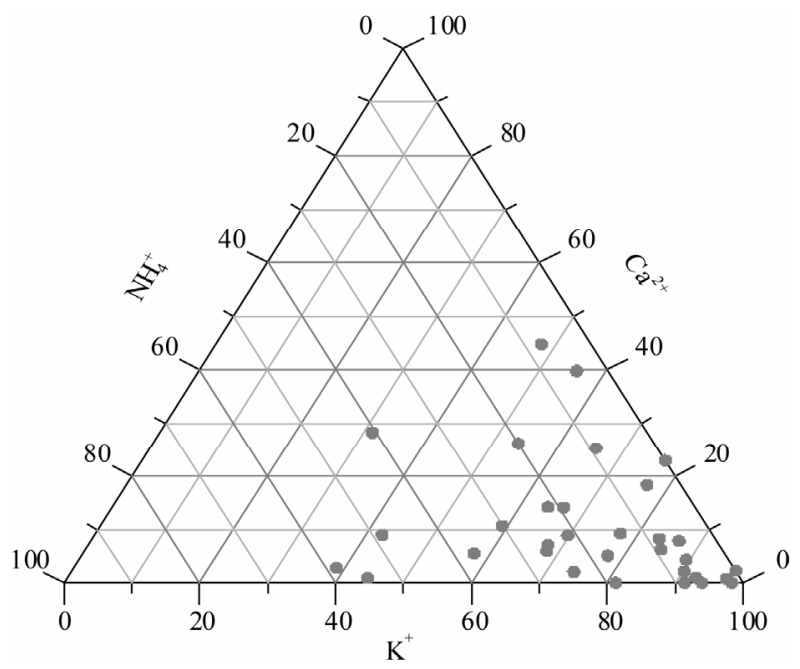

Figure 8. Triangular diagram relating neutralization factor (NF) of $\mathrm{Ca}^{2+}, \mathrm{K}^{+}$and $\mathrm{NH}_{4}^{+}$. 


\subsection{Principal Component Analysis}

Factor analysis is a useful statistical tool and it can be applied condensing the information contained in a number of variables into a smaller set of new composite dimensions [14]. Principal component analysis (PCA), a linear method for multivariate ordination was used to visualize the relationship among trace elements, focused to identify the possible sources of the major ions. ANOVA test by permutation were performed in order to test the significance of the factors to explain the found variations.

Figure 9 shows the variability pattern present in the multivariate data set for dry deposition in Manzanillo. Table 5 shows the factor loadings of the four major PC's together representing $\sim 39 \%$ of the total variance. PC2, PC 3 and PC4 accounted for $28.82 \%, 42.93 \%$ and $32.34 \%$ of the total variance, respectively. The identified factors are quite complex and represent mixed interactions between anthropogenic and natural effects. In dry deposition, dynamic factors like marine influence probably are of substantial importance along with crustal particle effects rather than purely anthropogenic emissions.

Only PC1 showed eigenvalue $>1$, however, this factor accounted only for $7 \%$ of the total variance and showed high loadings for $\mathrm{NO}_{3}^{-}$and $\mathrm{SO}_{4}^{2-}$, indicating that $\mathrm{PC} 1$ was influenced by anthropogenic emissions, since, these elements have their origin in similar sources, probably fuel oil-fired power plants located upwind the site. PC2 showed high loadings for $\mathrm{Na}^{+}$and $\mathrm{Cl}^{-}$indicating that this factor was influenced by a possible marine origin, since these elements are derived from marine aerosols.

PC3 showed high loadings for $\mathrm{Ca}^{2+}, \mathrm{Cl}^{-}$and $\mathrm{pH}$, showing a negative correlation between $\mathrm{Ca}^{2+}$ and $\mathrm{pH}$, indicating the influence of this element in the neutralizing process, probably soil particles. PC4 showed high loadings for $\mathrm{NH}_{4}^{+}, \mathrm{Ca}^{2+}$ and $\mathrm{Mg}^{2+}$, indicating that this factor was influenced by mixed sources (secondary emissions + crustal). In our study, the number of the identified factors was rather low and they had quite a complex character and the apportioning does not seem very informative since dry deposition had mixed sources in this site.

\subsection{Dry Deposition Fluxes and Critical Loads}

Even if average $\mathrm{pH}$ values were almost neutral; it is necessary to determine deposition fluxes of the species of interest due to these are the most important parameters to estimate the pollution effect regional or local in a zone. This information is necessary to estimate the real effects on natural ecosystems. The average dry deposition fluxes (in $\mathrm{Kg} \cdot \mathrm{ha}^{-1} \cdot \mathrm{yr}^{-1}$ ) ranged between 0.03 and 3.38. From Figure 10, it can be observed that dry fluxes showed a great variability. $\mathrm{NO}_{3}^{-}, \mathrm{SO}_{4}^{2-}$ and $\mathrm{K}^{+}$showed the highest fluxes, indicating that local sources contributed significantly to deposition of these trace elements. Since the sampling site was located downwind power plants and

\section{Dry Deposition at Manzanillo}

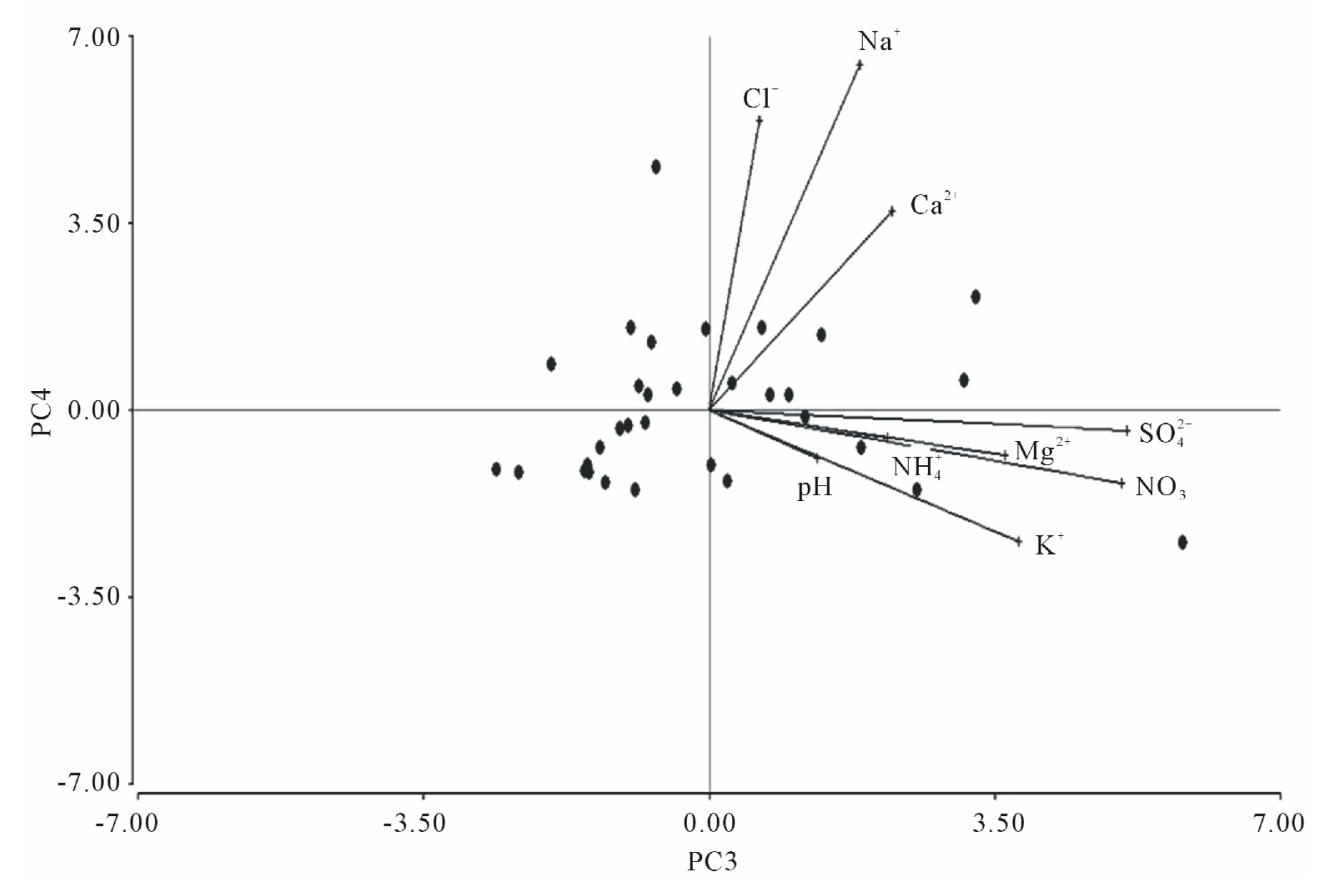

Figure 9. PCA results of factor identification for analytical data of Manzanillo. 
Table 5. Factor loading of the four major principal components for the data set of the studied site using PCA. Only loadings higher than 0.30 are reported.

\begin{tabular}{ccccc}
\hline Variables & PC1 & PC2 & PC3 & PC4 \\
\hline $\mathrm{Na}^{+}$ & - & 0.66 & - & - \\
$\mathrm{K}^{+}$ & 0.39 & - & - & - \\
$\mathrm{Ca}^{2+}$ & - & 0.38 & 0.5 & -0.32 \\
$\mathrm{Mg}^{2+}$ & 0.37 & - & - & -0.54 \\
$\mathrm{NH}_{4}^{+}$ & - & - & 0.36 & 0.64 \\
$\mathrm{NO}_{3}^{-}$ & 0.52 & - & - & - \\
$\mathrm{SO}_{4}^{2-}$ & 0.53 & - & - & - \\
$\mathrm{Cl}^{-}$ & - & 0.56 & -0.47 & - \\
$\mathrm{pH}^{-}$ & - & - & -0.44 & - \\
eigenvalue & 2.66 & 0.94 & -0.33 & -0.03 \\
\% of Variance & 2.74 & 11.22 & 12.38 & 12.59 \\
Cumulative \% & 2.74 & 13.96 & 26.34 & 38.93 \\
\hline
\end{tabular}

Note: Indicates that factor loading was minor than 0.30 .

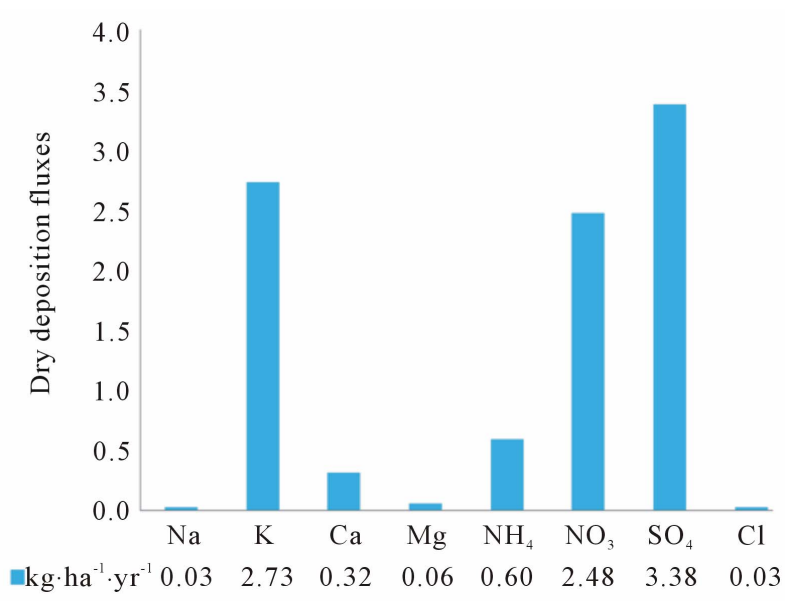

Figure 10. Dry deposition fluxes for Manzanillo.

the mining complex (it was confirmed from meteorological analysis: wind roses and air-mass backward trajectories), it can be expected that elements such as nitrate, sulfate and potassium contributed in a great proportion to the total dry deposition fluxes.

Dry deposition flux for $\mathrm{SO}_{4}^{2-}$ was higher than $\mathrm{NO}_{3}^{-}$, it is according to the residence times in the atmosphere of their precursors $\left(\mathrm{NO}_{\mathrm{x}}\right.$ and $\left.\mathrm{SO}_{2}\right)$, since it is well known that $\mathrm{NO}_{\mathrm{x}}$ are deposited around the emission point (local pollutant) whereas $\mathrm{SO}_{2}$ undergo long-range transport processes being deposited in distant places from the source (regional pollutant). It is difficult to estimate the contribution of these long-range transport processes since wet deposition was not measured, however, it has been reported that during the summer, prevail winds come from Guadalajara City, it can explain the regional component for sulfate levels found in Manzanillo.

Critical loads have been defined as the amount of one chemical compound that one ecosystem can tolerate before show damages. Several studies about critical loads for $\mathrm{N}$ and $\mathrm{S}$ using sensitive species have been reported, however, in Mexico, only a few studies in pine wood and oak forests in Mexico Valley have been carried out, and data about critical loads are not available [15-18].

From Figure 10, it can be observed that nitrogen deposition in Manzanillo is lower than $5 \mathrm{Kg} \cdot \mathrm{N} \cdot \mathrm{ha}^{-1} \cdot \mathrm{yr}^{-1}$, the critical load value reported for sensitive ecosystems in Europe [19]. However, considering that the hemispheric values reported for tropical remote sites range between 1 to $3 \mathrm{Kg} \cdot \mathrm{N} \cdot \mathrm{ha}^{-1} \cdot \mathrm{yr}^{-1}[20,21]$, nitrogen dry deposition at Manzanillo is already in the upper extreme of this threshold value. Even at this moment, nitrogen deposition is not a problem, it is necessary to take steps to avoid that nitrogen deposition exceed critical loads. In addition, it is necessary to mention that this study only reported dry deposition data. Critical loads used as reference values in this discussion correspond to total deposit (wet + dry deposition), therefore, fluxes reported in Figure $\mathbf{1 0}$ are sub-estimated since the contribution of wet deposition was not considered.

On the other hand, sulfur deposition at Manzanillo exceeded slightly the critical load value reported by Grennfelt and Nilsson [22] for sensitive ecosystems (3 $\mathrm{Kg} \cdot \mathrm{S} \cdot \mathrm{ha}^{-1} \cdot \mathrm{yr}^{-1}$ ), In addition, the hemispheric value reported by Galloway et al. [21] for remote sites $(0.5$ $\mathrm{Kg} \cdot \mathrm{S} \cdot \mathrm{ha}^{-1} \cdot \mathrm{yr}^{-1}$ ) was exceeded almost 7 times, it suggests sulfur deposition is already an environmental problem in this site, considering that the contribution of wet deposition was not included. Therefore, it is necessary to achieve monitoring programs to assess trends and to set goals that let to carry out an adequate environmental management of this site.

\section{Conclusions}

The study of dry deposition in Manzanillo, showed high content of $\mathrm{K}^{+}$and $\mathrm{NH}_{4}^{+}$as the dominant cations and high content of $\mathrm{SO}_{4}^{2-}$ followed by $\mathrm{NO}_{3}^{-}$, as the most important anions. Even though, there are two power plants within this city and it could be expected that the dry deposition would be acidic, the contribution of alkaline components was significant resulting in dry deposition with $\mathrm{pH}$ values relatively high.

It can be concluded that in Manzanillo, there is a complex environment with mixed sources driving the atmospheric chemistry (crustal, anthropogenic, marine aerosol, and secondary emissions) that results in $\mathrm{pH}$ values almost neutral, where alkaline particles with an anthro- 
pogenic origin probably play an important role in the neutralization process. Potassium contributed in a significant way to the neutralization process, suggesting probably the presence of $\mathrm{KNO}_{3}$ and $\mathrm{K}_{2} \mathrm{SO}_{4}$ in the atmosphere.

It is necessary to appoint that $\mathrm{pH}$ itself; it is not a conservative tracer of the potential ecological effects as a result of the emissions of acid precursors. In spite of, obtained $\mathrm{pH}$ values in dry deposition samples in this site were not in the acid range, the atmospheric deposition fluxes of $\mathrm{S}$ and $\mathrm{N}$ could represent a threat to the ecosystems. Therefore, local strategic policies focused to protect the ecosystems in this region should be applied.

\section{Acknowledgements}

This work was financially supported by Sectorial Fund CONACYT-SEMARNAT (project 107948).

\section{REFERENCES}

[1] J. D. Shannon and E. C. Voldner, "Estimation of Wet and Dry Deposition of Pollutant Sulfur in Eastern Canada as a Function of Major Source Regions," Water, Air, \& Soil Pollution, Vol. 18, No. 1-3, 1982, pp. 101-104. doi:10.1007/BF02419405

[2] M. Flues, P. Hama, M. J. L. Lemes, E. S. K. Dantas and A. Fornaro, "Evaluation of the Rainwater Acidity of a Rural Region Due to Coal-Fired Power Plant in Brazil," Atmospheric Environment, Vol. 36, No. 14, 2002, pp. 2397-2404. doi:10.1016/S1352-2310(01)00563-5

[3] P. Brimblecombe, “Acid Rain $2000+1000$," Water, Air, \& Soil Pollution, Vol. 130, No. 1-4, 2001, pp. 25-30. doi:10.1023/A:1012235015654

[4] R. Balestrini, L. Galli and G. Tartari, "Wet and Dry Atmospheric Deposition at Prealpine and Alpine Sites in Northern Italy," Atmospheric Environment, Vol. 34, No. 9, 2000, pp. 1455-1470. doi:10.1016/S1352-2310(99)00404-5

[5] H. G. Padilla, R. Belmont, M. B. Torres and A. Baez, "Hurricanes Pauline and Nora Rainwater Chemical Composition," Canadian Journal of Earth Sciences, Vol. 37, No. 4, 2000, pp. 569-578. doi:10.1139/e99-114

[6] R. Alonso, A. Bytnerowicz, J. L. Yee and W. I. Boarman, "Atmospheric Dry Deposition in the Vicinity of the Salton Sea, California-II: Measurement and Effects of an Enhanced Evaporation System," Atmospheric Environment, Vol. 39, No. 26, 2005, pp. 4681-4689. doi:10.1016/j.atmosenv.2005.04.017

[7] J. N. Galloway, J. D. Thornton, S. A. Norton, H. L. Volchok and R. A. N. McLean, "Trace Metals in Atmospheric Deposition: A Review and Assessment," Atmospheric Environment, Vol. 16, No. 7, 1982, pp. 1677-1700. doi:10.1016/0004-6981(82)90262-1

[8] A. P. Casimiro, M. L. Salgueiro and V. T. Núñez, "Seasonal and Air-Mass Trajectory Effects on Rainwater Quality at the Southwestern European Border," Atmos- pheric Environment, Vol. 25 A, 1991, pp. 1197-1204.

[9] R. Chester, M. Nimmo, K. J. T. Murphy and E. Nicholas, "Atmospheric Trace Metals Transported to the Western Mediterranean: Data from a Station on Cap Ferrat," Proceedings of Second EROS 2000 Workshop, Blanes, 1990, pp. 597-612.

[10] F. Culkin and R. A. Cox, "Sodium, Potassium, Magnesium, Calcium and Strontium in Sea Water," Deep Sea Research, Vol. 13, 1966, pp. 789-804.

[11] A. W. Morris and J. P. Riley, "The Bromide/Chlorinity and Sulphate/Chlorinity Ratio in Sea Water," Deep Sea Research, Vol. 13, 1966, pp. 699-705.

[12] R. M. Cerón, J. G. Cerón and M. Muriel, "Influence of Geochemical and Anthropogenic Sources on Rainwater Chemical Composition in Two Coastal Sites Impacted by the Gas and Oil Industry in Campeche, Mexico," WIT Transactions on Ecology and the Environment, Vol. 88, 2006, pp. 419-428.

[13] R. Tsitouridou and Ch. Anatolaki, "On the Wet and Dry Deposition of Ionic Species in the Vicinity of Coal-Fired Power Plants, Northwestern Greece," Atmospheric Research, Vol. 83, No. 1, 2007, pp. 93-105. doi:10.1016/j.atmosres.2006.03.005

[14] J. C. Davies, "Statistics and Data Analysis in Geology," John Wiley, New York, 1986.

[15] M. E. Fenn, L. I. de Bauer, A. Quevedo-Nolasco and C. Rodríguez-Frausto, "Nitrogen and Sulphur Deposition and Forest Nutrient Status in the Valley of Mexico," Water, Air, \& Soil Pollution, Vol. 113, No. 1-4, 1999, pp. 155-174. doi:10.1023/A:1005033008277

[16] D. Alvarado and T. Hernández, "Decline of Sacred Fir in the Desierto de los Leones National Park," In M. E. Fenn, L. I. De Bauer and T. Hernández, Eds., Urban Air Pollution and Forests: Resources at Risk in the Mexico City Air Basin, Ecological Studies Series, Springer-Verlag, New York, Vol. 156, 2002, pp. 243-260.

[17] M. Pérez, M. E. Fenn, V. M. Cetina and A. Aldrete, "The Effects of Canopy Cover on Throughfall and Soil Chemistry in Two Forrest Sites in the Mexico City Air Basin," Atmósfera, Vol. 21, 2008, pp. 83-100.

[18] A. G. Ponette, K. C. Weathers and L. M. Curran, "Tropical Land-Cover Change Alters Biogeochemical Inputs to Ecosystems in a Mexican Montane Landscape," Ecological Applications, Vol. 20, No. 7, 2010, pp. 1820-1837. doi:10.1890/09-1125.1

[19] E. Hiltbrunner, "How Responsive Are Alpine Plants and Communities to Increased Nitrogen Deposition," Proceedings C.E.E. Workshop on Modeling and Mapping, Berne, 2008.

[20] H. Rodhe, J. Langner, L. Gallardo and L. Kjellström, "Global Scale Transport of Acidifying Pollutants," Water, Air, \& Soil Pollution, Vol. 85, No. 1, 1995, pp. 37-50. doi:10.1007/BF00483687

[21] J. N. Galloway, A. R. Townsend, J. W. Erisman, M. Bekunda, Z. C. Cai, J. R. Freney, L. A. Martinelli, S. P. Seitzinger and M. A. Sutton, "Transformation of the Nitrogen Cycle: Recent Trends, Questions, and Potential Solutions," Science, Vol. 320, 2008, pp. 889-892. 
doi:10.1126/science.1136674PMid:18487183

[22] P. Grennfelt and J. Nilsson, "Critical Loads for Sulphur and Nitrogen," The Nordic Council of Ministers Report, Copenhagen, 1988. 